Tropical Bryology 11: 5-9, 1995

\title{
The influence of leaf characteristics on epiphyllic cover: a test of hypotheses with artificial leaves
}

\author{
Julian Monge-Najera and Mario A. Blanco \\ Biología Tropical, Universidad de Costa Rica, Costa Rica.
}

\begin{abstract}
Studies of epiphyll ecology have been hindered by the biochemical and morphological variability of the leaf substrate. The use of artificial (plastic ribbon tape) leaves solved that problem in a study done at the Braulio Carrillo National Park, Costa Rica. It showed that after nine months of field exposure, relative epiphyll cover was similar in five leaf shapes and two sizes. Driptips do not affect epiphyll cover, which was four times higher under a clearing than in the shaded understory, for all leaf shapes and sizes.
\end{abstract}

The leaves of certain species appear to be preferred or avoided by epiphylls, but the reasons for this are poorly known (review in Richards 1984). Olarinmoye (1975) and Monge-Nájera (1989) have analysed the influence of light, as well as some leaf characters, by comparing forest and clearing leaves of several species and age classes. Nevertheless, both authors concluded that the use of several leaf species obscured the individual role of ecological factors (Richards 1984, Monge-Nájera 1989). To overcome this difficulty, a study in Monteverde, Costa Rica, additionally compared leaves of a single species of Piper (Monge-Nájera 1989), but the single-species approach offers a very limited set of leaf characteristics to compare.

This paper presents a further step in the isolation of factors influencing epiphyll cover, obtained by the use of artificial leaves, a technique inspired in the discovery that some epiphylls grow on artificial substrates (Winkler 1967). Colonization on artificial leaves is not influenced by specific biochemical or microstructural differences in the substrate, allowing the strict experimental manipulation of factors such as leaf shape and size.

\section{MATERIALSANDMETHODS}

Artificial leaves were made from green plastic ribbon tape and produced in five different shapes and two sizes for one shape (Figure 1). They were placed with pins on soft wood blades which were hanged horizontally in the understory, about 1.5 $m$ from the ground, adjacent to the Botarrama Trail, BraulioCarrilloNationalPark(1009'16"N, 8356'43" W,Limón province, Costa Rica, ca.500m. altitude). The site is in the "Subtropical-Tropical Very Moist Without Dry Season" biotic unit type (Herrera and Gómez 1993). Toassess the effect of light incidence on epiphyll growth, one set of leaves was placed under a closed canopy and the other in a small 

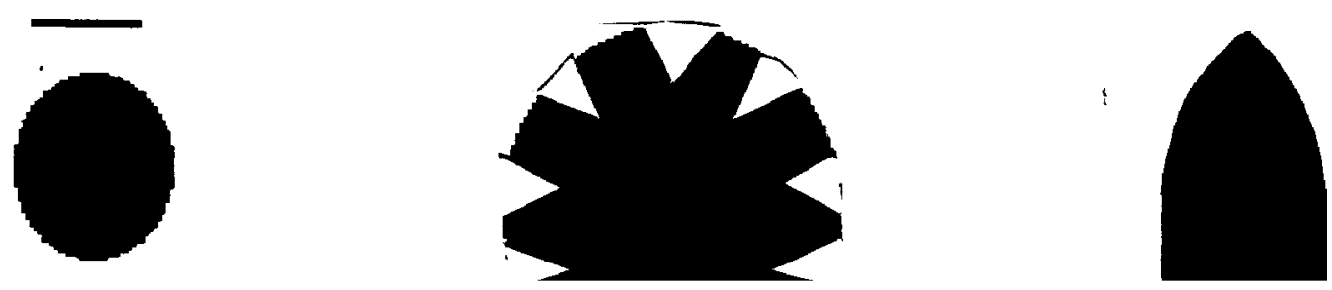

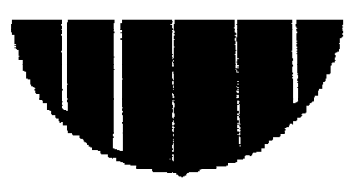

PLEATED

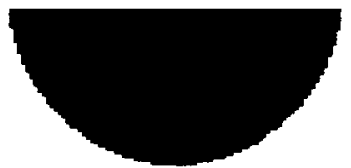

DRIPTIP

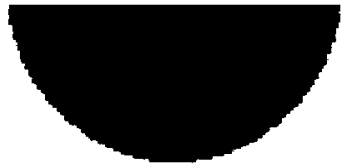

STANDARD

Figure 1: Shapes of the artificial leaves used. The "small" type has the same shape as the "standard" type, but has only a third of its area. 1: standard, 2: driptip, 3: pleated, 4: narrow, 5: cleft, 6: small. Scale $=$ $\mathrm{cm}$.

clearing.

Afternine and a half months (from November 1991 to September 1992) the artificial leaves were removed from the site, and epiphyll cover was measured with an acetate grid (points every $3 \mathrm{~mm}$ ) with the help of a dissecting microscope at 20X. Percent of relative cover $=$ (points over epiphylls/ total points over leaf) $x 100$. Only epiphyllic cover due to bryophytes was measured (i.e. lichens and algae were not taken into account).

\section{RESULTS}

Epiphyllous bryophytes, as well as lichens, algae and bacteria were able to colonize the plastic surface in a similar way to that on natural leaves. They were even growing on the fishing line used to hold the wooden blades in place. Bryophytes were mostly foliose liverworts (chiefly Lejeunea- ceae), but moss plants of the genus Crossomitrium were also seen. Almost all colonizing bryophytes belonged to species which disperse by asexual propagules (M.I. Morales, personal communication 1992). Several species of liverworts had already developed sexual structures such as archegonial shoots and perianths.

There was no significant difference in relative cover among the five leaf shapes nor between the two sizes (Kruskal-Wallis ANOVA, p>0.05; Table $1)$.

Relative cover was higher under the clearing (Mann-Whitney U,p<0.0001). Artificial leaves in the understory averaged $2.9 \%$ cover, while those in the clearing averaged $12.3 \%$.

\section{DISCUSSION}


Table 1: Leaf type and relative epiphyll cover using artificial leaves. $\mathrm{N}=$ number of leaves. = standard deviation.

\begin{tabular}{|c|c|c|c|c|c|}
\hline Type & $\mathbf{N}$ & & Mean & & Range \\
\hline Standard & 125 & & 7.9 & 9.3 & $0-49.5$ \\
\hline Driptip43 & & 7.3 & & 8.4 & $0-30.4$ \\
\hline Pleated & 38 & & 11.5 & 12.6 & $0-45.8$ \\
\hline Narrow & 39 & & 6.6 & 7.7 & $0-30.9$ \\
\hline Cleft & 42 & & 9.0 & 9.7 & $0-46.5$ \\
\hline Small & 30 & & 5.2 & 5.4 & $0-17.6$ \\
\hline
\end{tabular}

Colonization of artificial substrates and the epiphyll-host relationship

The question of whether epiphylls are parasites or even mutualists of vascular plants is frequently asked in the literature (Winkler 1967, Berrie and Eze 1975, Bentley and Carpenter 1980, Pócs 1982, Richards 1984). For example, there is evidence that epiphylls, which appear to be well protected chemically, may benefit the host by reducing herbivory (Mueller and Wolf-Mueller 1991). Our results show that at least some species can colonize substrates with which parasitic and mutualistic associations are not possible, although it does not mean that such associations are absent in nature. Winkler (1967) also showed that epiphyll bryophytes were able to grow on grinded glass slides.

Colonization of artificial leaves also supports previous reports that epiphylls are not species specific in their use of substrate (Kjeldbjerg 1987), although host specificity may become important under conditions of stress, such as low water availability (Olarinmoye 1975). Microhabitat humidity, light and nutrients transported by rainwater, dust, animals and falling microdebris apparently were enough for successful colonization of the artificial substrate.

Relative cover

Relative cover was very similar in artificial (11.5\%, this study) and natural leaves (12\%, Monge-Nájera
1989) in Costa Rica. Values reported for Panama were higher (Coley et al. 1993). We have no data about the environmental factors which probably are responsible for such regional differences, although humidity probably is determinant (Monge-Nájera 1989).

\section{Role of environmental factors}

Water - The structure of many plant communities is a function of the ratio of available water and energy (Stephenson 1990). Currently there are no appropriate data to test that generalization on epiphyll communities, but there is much qualitative evidence suggesting that a higher proportion of available water is required by epiphyllous liverworts than by epiphyllous lichens (Olarinmoye 1975, Richards 1984, Coley et al. 1993). In contrast, heavy direct rain appears to prevent development of all epiphylls (Olarinmoye 1975), but all previous reports were unable to separate water effects from host characteristics. The results with artificial substrates suggest that direct rainfall is not deleterious per se because colonization was better in the clearing. Besides, the less humid conditions in the clearing had no negative effect on epiphylls, possibly because the study site is a generally moist habitat.

Light - There are conflicting reports on the positive and negative effect of high light levels on epiphylls (Olarinmoye 1975). In some cases, the cover with foliicolous lichens increases towards 
the lower, less illuminated parts of the foliage (Schell and Winkler 1981). Other field evidence suggests that at least some liverworts are photophilic(Olarinmoye 1975, Monge-Nájera 1989, Coley etal. 1993).

In this experiment, liverworts grew better under higher light levels, perhaps because an understory may receive as little as $1-2 \%$ of the light reaching the canopy (A. and R. Lücking, pers. com.) reducing liverwort growth rate. Finally, the possibility that leaves are more easily reached by propagules in the clearing remains to be tested.

\section{Leaf characteristics}

The relative cover did not differ among leaf shapes. This result reduces support for some previous hypotheses (for reviews, see Olarinmoye 1975 and Richards 1984); however, significant differences in epiphyll cover might be obtained if more dissimilar leaf types were used. Results of further investigation in this respect will be presented in a future contribution.

Theory predicts that elongated leaves distribute light better and are advantageous in evergreen species with efficient photosynthesis (Sprugel 1989). Many plants in the generally humid and dark rainforest understory satisfy the above conditions and have the need to optimize light reception if covered by epiphylls, as can be deducted from Coley et al.'s (1993) report that epiphylls can decrease light reception by $20-30 \%$ and probably photosynthesis by $15-40 \%$.

Leaves in clearings were found to be more elongated that those in the understory in Monteverde, but they did not differ in their relative epiphyllic cover (Monge-Nájera 1989).

Olarinmoye (1975) found in Nigeria that epiphylls appear to avoid finely divided leaves, probably because they offer less landing surface for falling propagules. This relation was not found when using the artificial leaves, but our "cleft" leaf type is not finely divided enough to be compared to such leaves.

Leaf driptips have been the subject of considerable speculation. They may increase water flow on the leaf surface, thus having either a negative effect on epiphyll cover by washing away epiphyll propagules or a positive effect by increasing propagule dispersal, but Olarinmoye (1975) believed that driptips were unsignificant for epi- phyllic communities. Our qualitative observations on natural and artifical leaves in the field support Lightbody's debated statement that driptips cause water to be shed more rapidly (Lightbody 1985, 1986; Williamson 1986). Recent work by Ellenberg (1985) suggest that driptips have no real primary ecological function. Nevertheless, the absence or presence of a driptip did not affect relative cover in the artificial leaves.

The use of artificial leaves should be applied in the future to check other generalizations, such as the lack of importance of leaf texture (Olarinmoye 1975, Coley et al. 1993) and trichomes (Olarinmoye 1975).

Substrate stability is basic for epiphylls, and canopy leaves which are commonly deciduous often lack them, in contrast with the long-lived understorey leaves (Olarinmoye 1975). Periodic leaf shedding in tropical plants most probably originated as a way of avoiding excessive water loss during drought periods (Chabbot and Hicks 1982), but it could serve as well as a mechanism for getting rid of the epiphylls in habitats where the dry season is not so severe. In the tropical rainforest, about $40 \%$ of leaves live at least two years (Bentley 1979) but in any case selection probably favoured short life cycles in epiphylls (Richards 1984). The significant cover reached here in only nine months supports the idea of rapid development, but a more valid conclusion requires meaningful comparison with non-epiphyllous relatives. A detailed study regarding the relationship between leaf life-span and epiphyll colonization (using the artificial leaf approach) will be presented in a future paper.

Qualitative observations suggest that in Nigeria leaf size is unrelated to epiphylly (Olarinmoye 1975) while in the only previous case in which leaf size was studied quantitatively, larger leaves (which are more common in clearings) had more absolute epiphyll cover, but not a higher relative cover (Monge-Nájera 1989). This observation is also valid for artificial leaves, suggesting that in nature, total area colonized is a function of total leaf area available.

\section{ACKNOWLEDGMENTS}

We would like to thank Zaidett Barrientos and Esther Domínguez for field assistance. Robert Lücking, Rob Gradstein and María Isabel Morales made suggestions to 
improve an earlier draft.

\section{LITERATURE CITED}

Bentley, B.L. 1979. Longevity of individual leaves in a tropical rain forest understory. Annals of Botany 43: 119-121.

Bentley, B.L. \& E.J. Carpenter. 1980. Effects of dessication and rehydration on nitrogen fixation by epiphylls in a tropical rain forest. Microbiological Ecology 6(2): 109-114.

Berrie, G.K. \& J.M.O. Eze. 1975. The relationship between an epiphyllous liverwort and host leaves. Annals of Botany 39: 955-963.

Chabbot, B.F. \& D.J. Hicks. 1982. The ecology of leaf life spans. Annual Review of Ecology and Systematics 13: 229-259.

Coley, P.D., T.A. Kursar \& J.L. Machado. 1993. Colonization of tropical rain forest leaves by epiphylls: effects of site and host plant leaf lifetime. Ecology 74(2): 619-623.

Ellenberg, H. 1985. Unter welchen Bedingungen haben Blätter sogenannte 'Traüfel spitzen'. Flora 176: $169-188$

Herrera, W. \& Gómez, L.D. 1993. Mapa de unidades bióticas de Costa Rica. Instituto de Caza Fotográfica, San José, Costa Rica. (1:685000).

Lightbody, J.P. 1985. Distribution of leaf shapes of Piper sp. in a tropical cloud forest: evidence for the role of driptips. Biotropica 17(4): 339342.

Lightbody, J.P. 1986. Pitchers with spouts empty faster. Biotropica 18(4): 360.

Monge-Nájera, J. 1989. The relationship of epiphyllous liverworts with leaf characteristics and light in Monteverde, Costa Rica. Cryptogamie, Bryologie-Lichénologie 10(4): 345-352.

Mueller, U.G. \& B. Wolf-Mueller. 1991. Epiphyll deterrence to the leafcutter ant Atta cephalotes. Oecologia (Berlin) 86: 36-39.

Olarinmoye, S.O. 1975. Ecological studies of epiphyllous liverworts in Western Nigeria. II. Notes on competition and succesional change. Revue Bryologique et Lichénologique 41: 457463.

Pócs, T. 1982. Tropical forest bryophytes. Pages 59-104 in A.J.E. Smith, editor. Bryophyte Ecology. Chapman and Hall, London, England.
Richards, P.W. 1984. The ecology of tropical forest bryophytes. Pages 1233-1270 in R.M. Schuster, editor. New manual of bryology. Volume 2. Hattori Botanical Laboratory, Nichinan, Japan.

Schell, S. \& S. Winkler. 1981. Zur Ökologie und Pflanzengeographie Blattbewohnender Flechten von Rio Grande do Sul (Südbrasilien). Cryptogamie, Bryologie-Lichénologie 2(3): 323-343.

Sprugel, D.G. 1989. The relationship of evergreenness, crown architecture, and leaf size. American Naturalist 133(4): 465-479.

Stephenson, N.L. 1990. Climatic control of vegetation distribution: the role of the water balance. American Naturalist 135(5): 649-670.

Williamson, G.B. 1986. Do pitchers with spouts pour faster? Biotropica 18(4): 360.

Winkler, S. 1967. Die epiphyllen Moose der Nebelwälder von El Salvador, C. A. Revue Bryologique et Lichénologique 35: 303-369. 